\title{
QTL explaining variation in production traits and udder health in the Danish Holstein population
}

\author{
Hauke Thomsen', Jørn R. Thomasen², Bernt Guldbrandtsen' and Mogens S. Lund' \\ 'Department of Genetics and Biotechnology, University of Aarhus, P.O. Box 50, Tjele, Denmark, ²Viking Genetics, \\ Ebeltoftvej 16, Assentoft, Randers, Denmark
}

\section{Abstract}

The main objective was to locate QTL and estimate the proportion of total genetic variance attributable to quantitative trait loci (QTL) for production index traits and the udder health index identified on six Bos taurus autosomes in the Danish Holstein dairy cattle population.

Data were obtained from a granddaughter design of 20 sire families with a total of 1869 progeny tested sons. The number of sons per grandsire ranged from 20 to 284, with an average family size of 93.5 . Indexes of the estimated breeding values were obtained for the milk production traits and for the udder health index from the Danish Agricultural Advisory Service database.

A random-QTL model was applied to incorporate marker information into parameter estimation for each single QTL. The procedure allowed us to detect new QTL on BTA3, BTA16 and BTA28 and to estimate the proportion of total genetic variance attributed to different QTL on a total of six Bos taurus autosomes for the udder health index and yield index traits in the Danish Holstein population. Variance estimates vary between 2 to $58 \%$ of the total variance for different QTL and seem to explain a substantial part of the variance at certain positions of the cattle genome.

The results are discussed against the background of the failure of marker-assisted selection (MAS) and the recent availability of large panels of single nucleotide polymorphisms (SNPs) that have improved the search for mutations underlying variation in complex traits resulting in modern genomic selection.

Keywords: QTL, marker assisted selection, variance component

\section{Zusammenfassung}

\section{Varianzkomponenten für QTL der Leistungsmerkmale und Eutergesundheit in der Dänischen Holstein Population}

Ziel derUntersuchung war das Auffinden von QTL und dieSchätzung von Varianzkomponenten für QTL der Leistungsindexmerkmale und des Eutergesundheitsindex in der dänischen Holstein Population. Zu diesem Zweck wurde ein Enkelinnen-Design von 20 Großvätern mit einer Gesamtzahl von 1869 Nachkommen-getesteten Söhnen untersucht. Die Anzahl der Söhne je Großvater variierte von 20 bis 284, wobei die durchschnittliche Familiengröße bei 93,5 Söhnen je Großvater lag. Die verwendeten Indexzuchtwerte für die untersuchten Merkmale wurden aus der Datenbank des dänischen Agrarberatungsservices extrahiert. 
Für die Schätzung wurde ein zufälliges QTL Modell angewendet, dass die gesamte genetische Varianz in einen polygenetischen Anteil und einen Anteil, der der Segregation eines QTL zuzuschreiben ist, unterteilt. Die Untersuchung führte zur Identifizierung neuer QTL auf den Chromosomen 3, 16 und 28. Die entsprechend geschätzten QTL Varianzkomponenten aller QTL auf sechs Chromosomen variierten dann je nach Merkmal zwischen 2 und $58 \%$ der entsprechenden totalen genetischen Varianz.

Die Ergebnisse wurden anschließend vor dem Hintergrund der Schwierigkeiten bei der Durchführung der Markergestützten Selektion (MAS) und der Einführung der genomischen Selektion in die Tierzucht kritisch hinterfragt.

Schlüsselwörter: QTL, markergestützte Selektion, Varianzkomponenten

\section{Introduction}

Most economically important traits in livestock species are quantitative by nature. These traits are influenced by many chromosomal regions, which are often referred to as quantitative trait loci (QTL). Many QTL have been identified in dairy cattle for primary production and health traits such as milk, fat and protein yield, clinical mastitis and type traits (Georges et al. 1995, Zhang et al. 1998, Spelman et al. 1999, Schrooten et al. 2000, Klungland et al. 2001, Thomsen et al. 2001, Kühn et al. 2002, Hiendleder et al. 2003, Ron et al. 2004). Danish breeders have put their emphasis mainly on health and conformation traits (Buitenhuis et al. 2007, Lund et al. 2008, Thomasen et al. 2008).

Locating these QTL and understanding their inheritance is worthwhile for animal breeders as it enables them to estimate an animal's breeding value more accurately and apply markerassisted selection (MAS) as described by Fernando \& Grossman (1989). MAS is particularly useful when breeding for traits that are difficult or expensive to measure and/or are lowly heritable (Meuwissen \& Goddard 1996, Goddard \& Hayes 2002). Including random QTL effects in MAS is also useful in pre-selection of young candidates for progeny testing programs or the selection of heifers as candidates for dams of bulls. Well-described examples of MAS had been implemented in large-scale dairy cattle breeding schemes in New Zealand (Spelman et al. 2007), France (Boichard et al. 2002) and Germany (Bennewitz et al. 2004). In relation to this, Spelman et al. (2007) reported MAS to have led to minor to moderate improvement in genetic gain with, at best, a neutral cost-effectiveness.

The benefit of MAS is highly dependent on how accurately the location, effects, and the proportion of variance due to the polygenic and due to the QTL components are estimated (Lande \& Thompson 1990).

A special challenge in estimating variance components for QTL arises from the fact that usually only a small part of the overall population is genotyped. As for France, Germany and New Zealand, where MAS had been added to existing breeding programs, only genotyped animals provide information for the QTL-specific evaluations, and therefore specific approaches had to be established for the estimation of QTL variance components and subsequent MA-BLUP breeding value estimation (Bennewitz et al. 2004, Liu et al. 2004, Druet et al. 2006, Neuner et al. 2008, 2009). 
In principle, MAS involves selection on markers either in linkage disequilibrium (LD) or linkage equilibrium with the QTL. But as we have to perform very stringent tests for statistical significance to identify QTL, only a limited fraction of the genetic variation is explained by the identified QTL (Goddard \& Hayes 2009). Besides that the progress in identifying causal genes has been slow as linkage mapping results result still in large confidence intervals. The recent availability of large panels of single nucleotide polymorphisms (SNPs) has improved search for mutations underlying variation in complex traits. The clear advantage of genomic selection (GS) is targeting potentially all QTL simultaneously in contrast to MAS typically targeting only a few selected QTL. Thus, there has been an evolution from MAS towards GS (for example, Goddard \& Hayes 2007), and GS is now rapidly replacing traditional evaluation systems used for dairy cattle.

Despite this evolutionary development the objective of this study was twofold: first, scan for new QTL on chromosomes that have not yet been investigated for production and udder health indexes and secondly, estimate the proportion of total genetic variation attributed to QTL for production index traits and in particular for the udder-health trait index in Danish Holstein cattle.

\section{Material and methods}

\section{Animals}

Data used in this study was derived from a granddaughter design with Danish Holstein cattle. The design involved 20 sire families with 1869 progeny-tested sons. The number of sons per grandsire ranged from 20 to 284 and the average family size was 93.5. Each progeny tested sire had at least 70 daughters with records. Indexes of the estimated breeding values were obtained for the milk-production traits (Milk index, Ml; Protein Index, Pl; Fat index, $\mathrm{Fl}$; and the compound yield index, $\mathrm{YI}$ ) and for an udder-health index (UI) from the Danish Agricultural Advisory Service database. Details of methods and models used for breeding value estimation can be found in Danish Cattle Federation (2006).

As daughter-yield deviations (DYD) were not available for the observed traits, indexes of the estimated breeding values were de-regressed (de-regressed proofs=DRPF). The deregression as described by Lien et al. (1995) provides an approximate measure of daughteryield deviations.

In the subsequent statistical analysis the different number of daughters contributing to the calculation of de-regressed breeding values was accounted for by a weighting factor w,

$$
w=\frac{n_{e}}{1+\left(n_{e}-1\right) 1 / h_{4}^{2}}
$$

where the number of effective daughters of each sire is $n_{e}$ and $h^{2}$ is the heritability of the trait provided by the Danish Agricultural Advisory Service database. The weighting represents the variance of the DRPFs (Thomsen et al. 2001). 


\section{Pedigree information}

The pedigree for animals of the latest generation was calculated as described by Kučerová et al. (2006). However, we modified it to specifically account also for genetic relationships between grandsire families. All male and female ancestors of the grandsires and sons were traced back until unknown parents were reached. This resulted in a pedigree with 10134 animals that were related to the genotyped grandsires and their sons. The oldest ancestor in the pedigree was born in 1953.

\section{Markers and maps}

Grandsires and sons were genotyped for selected regions on the following chromosomes BTA3, BTA5, BTA7, BTA16, BTA23, and BTA28. Markers and their positions were selected from the Meat Animal Research Center (http://www.marc.usda.gov/genome/cattle/cattle. html; USDAMARC, Clay Center, USA). Details on marker typing, marker maps, distribution of markers across the chromosomes and the selection of the genomic regions are provided in Table 1 of Thomasen et al. (2008). Genotypes were produced on an automated sequence analyser. Inconsistent marker types or markers exhibiting evidence of segregation distortion were discarded.

Chromosomes for the current study have been chosen, because they harbour significant QTL for health traits such as clinical mastitis, somatic cell score, conformation and calving traits as described by Buitenhuis et al. (2007), Lund et al. (2008) and Thomasen et al. (2008), but have not been investigated for production index traits and the udder health index.

\section{Statistical analyses}

A random-QTL model, as described by Sørensen et al. (2003), was fitted to estimate variance components for each single trait. The model decomposes the overall genetic variance into a component due to the segregation of a putative QTL, and another due to the effect of a polygenic term (the collective effects of all other QTL affecting the trait).

The model can be written as:

$$
y=X \beta+Z u+W q+e
$$

where $y$ is a vector of de-regressed proofs, $X$ is a matrix relating records to the fixed effects, $\beta$ is a vector of fixed effects including the overall trait means, $Z$ is a matrix relating records to individuals, $u$ is a vector of polygenic effects, $W$ is a matrix relating each individual's record to its QTL effect, $q$ is a vector of additive QTL effects corresponding to the QTL, and $e$ is a vector of random residuals.

The random variables $u, q$ and $e$ are assumed to be multivariate normally distributed (MVN) and mutually uncorrelated. Specifically, $u$ is MVN $(0, G \otimes A), q$ is $M V N\left(0, K \otimes G R M_{i}\right)$, and e is $\operatorname{MVN}(0, E \otimes R)$.

$A$ is the additive genetic relationship matrix and $G M_{i}$ is the gametic relationship matrix (GRM) for the QTL ${ }_{\mid M, p}$ conditional on marker data (M) at the position $p$ of the QTL $i$ on the chromosome. $G, K$ and $E$ represent the variance-covariance structure of traits due to polygenic, additive QTL and residual effects, respectively. 
In a single-trait single-QTL model used for the current across family analysis $G, K$, and $E$ are reduced to scalars.

The most likely marker-linkage phase in the sire was used to compute the GRM as described by Wang et al. (1995) and extended by Sørensen et al. (2003) for flanking markers and with a second extension for both sexes.

The variance components were estimated using the average-information restricted maximum-likelihood algorithm (AIREML and DMU, Jensen et al. 1997). The restricted likelihood was maximized with respect to the variance components associated with the random effects in the model. Maximizing a sequence of restricted likelihoods over a grid of specific positions yields a profile of the restricted likelihood of the QTL positions. Parameters were estimated for every $\mathrm{cM}$ along each chromosome and yielded in the restricted likelihood of the QTL position (Sørensen et al. 2003).

Estimates of variance components were only considered for specific QTL locations, which have been suggested by Thomasen et al. (2008) to be used in subsequent MAS in Danish Holstein cattle.

The test statistic is based on the likelihood ratio test (LRT) as described by Kučerová et al. (2006), in which the presence of QTL were based on the asymptotic distribution of the LRT statistic with $L R T=-2 \ln \left(\mathrm{L}_{\text {reduced }}-\mathrm{L}_{\text {full }}\right)$, where $\mathrm{L}_{\text {full }}$ and $\mathrm{L}_{\text {reduced }}$ were the maximized likelihoods under the full model and the reduced model representing no QTL effect for the chromosome. Significant thresholds were calculated as described by Piepho (2001) at levels of $a=0.10,0.05$ and 0.01 .

\section{Results}

\section{QTL positions}

Using the expanded pedigree material as described above the single-trait single-QTL model was used to refine the precise locations of the QTL of pre-selected regions on chromosomes BTA3, BTA5, BTA7, BTA16, BTA23, and BTA28 and to subsequently estimate the variance components of the QTL at the maximized positions.

Likelihood profiles for the yield index and the udder health index on the respective chromosomes detected by the single-trait-single-QTL-analysis are shown in Figure 1 to 6 . The significance thresholds in the figures are shown for $5 \%$ chromosomewise, but significance of the results is also indicated in the Table 1. The axis of abscissae indicates the chromosomal positions and the ordinate shows the LRT statistics.

In total, 13 QTL for the production yield index traits, the compounded yield index and the udder health index were identified as to be significant on the chromosomes under investigation (Table 1). Table 1 also shows the corresponding significance and the related variance components. For the yield index, the QTL on BTA3 was just below the significance threshold, although the QTL profile was highest for the position that had been identified in the former regression analysis. Four QTL regions being significant for yield traits in previous investigations (FI on BTA5, YI on BTA5, YI on BTA23 and MI on BTA28) did not reach significance for yield index traits in our investigation. 


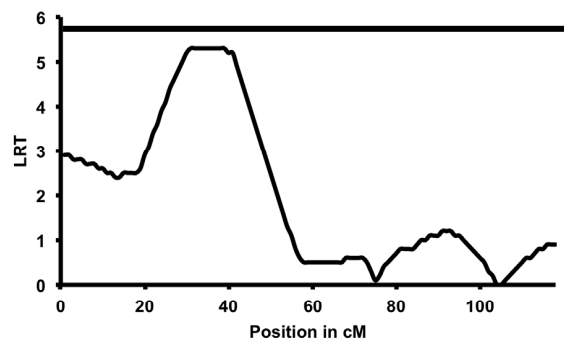

Figure 1

Loglikelihood ratio test statistic profile for Yield Index on BTA5

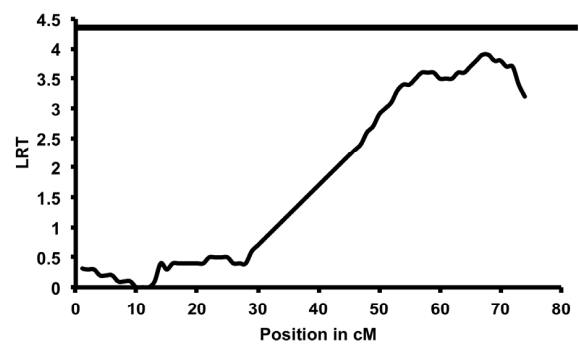

Figure 3

Loglikelihood ratio test statistic profile for Yield Index on BTA23

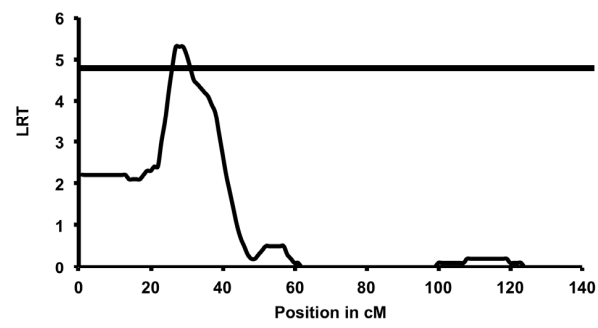

Figure 5

Loglikelihood ratio test statistic profile for Udder Health Index on BTA7

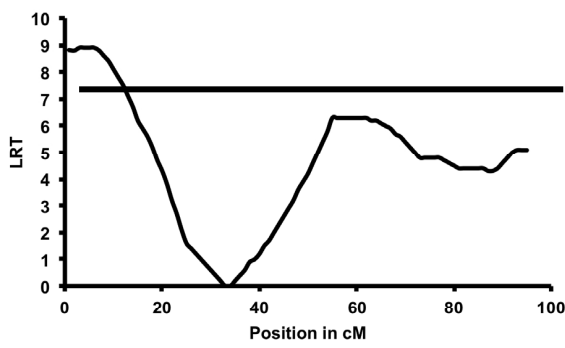

Figure 2

Loglikelihood ratio test statistic profile for Yield Index on BTA16

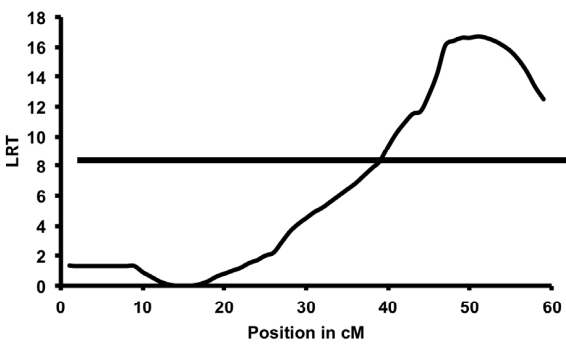

Figure 4

Loglikelihood ratio test statistic profile for Yield Index on BTA28

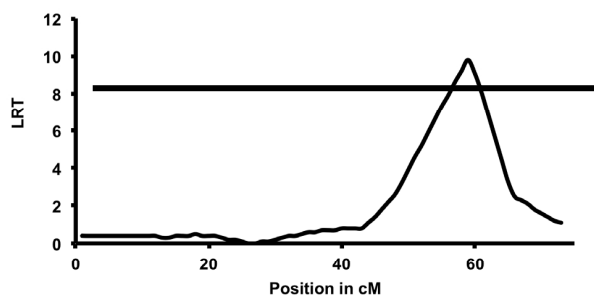

Figure 6

Loglikelihood ratio test statistic profile for Udder Health Index on BTA23

\section{Variance components}

Model 1 was applied to the data to partition total variance into the QTL, polygenic, and the residual components. Among all traits the polygenic variance was largest except for the protein and yield index on BTA28. Corresponding QTL variance estimates varied between 2 to $58 \%$. Despite the fact that some estimates of the QTL variances were relatively low, the QTL term was significant for almost all yield index traits and for the udder health index as shown in the Table 1. Although variance components for the compounded yield index were not significant on BTA3, BTA5 and BTA23, the same chromosomes were highly significant for the protein index, milk index or fat index and were, therefore, considered in the analysis of the compounded yield index as well. The overall estimates are shown in the Table 1 for the udder health index and the production index traits. 
Table 1

Variance Components for different traits

\begin{tabular}{lrrrrrr}
\hline BTA & Position $^{\text {a }}$ & Trait & LRT & QTL & PG & Rest \\
\hline 07 & $28(30)$ & UI & $5.3^{*}$ & $5.83 \pm 2.96$ & $87.97 \pm 9.84$ & $9.71 \pm 2.77$ \\
23 & $59(60)$ & UI & $9.8^{* *}$ & $6.72 \pm 3.35$ & $86.17 \pm 10.19$ & $7.65 \pm 2.91$ \\
23 & $56(66)$ & $\mathrm{FI}$ & $12.5^{* * *}$ & $4.27 \pm 3.60$ & $83.01 \pm 10.51$ & $17.87 \pm 5.93$ \\
05 & $46(40)$ & $\mathrm{MI}$ & $9.5^{* *}$ & $11.07 \pm 7.22$ & $72.39 \pm 16.67$ & $34.57 \pm 9.27$ \\
16 & $5(10)$ & $\mathrm{MI}$ & $12.2^{* *}$ & $7.60 \pm 5.19$ & $74.99 \pm 15.64$ & $36.40 \pm 9.82$ \\
23 & $59(60)$ & $\mathrm{MI}$ & $9.5^{* *}$ & $5.90 \pm 4.69$ & $79.50 \pm 15.07$ & $36.00 \pm 9.74$ \\
03 & $72(40)$ & $\mathrm{PI}$ & $8.0^{*}$ & $3.23 \pm 4.02$ & $91.85 \pm 12.13$ & $29.52 \pm 7.18$ \\
05 & $39(40)$ & $\mathrm{PI}$ & $11.2^{* *}$ & $12.79 \pm 8.52$ & $76.54 \pm 16.25$ & $28.47 \pm 6.84$ \\
16 & $8(10)$ & $\mathrm{PI}$ & $12.3^{* *}$ & $9.72 \pm 7.14$ & $79.30 \pm 15.36$ & $29.47 \pm 7.12$ \\
23 & $59(55)$ & $\mathrm{PI}$ & $13.2^{* * *}$ & $7.24 \pm 5.47$ & $84.90 \pm 13.17$ & $29.16 \pm 7.07$ \\
28 & $49(50)$ & $\mathrm{PI}$ & $7.8^{*}$ & $44.60 \pm 13.2$ & $20.99 \pm 21.51$ & $29.15 \pm 6.92$ \\
03 & $87(74)$ & $\mathrm{YI}$ & 6.3 & $4.04 \pm 1.54$ & $86.96 \pm 8.07$ & $25.37 \pm 2.74$ \\
05 & $38(40)$ & $\mathrm{YI}$ & 5.3 & $9.10 \pm 1.61$ & $78.92 \pm 7.76$ & $24.78 \pm 2.76$ \\
16 & $4(10)$ & $\mathrm{YI}$ & $8.9^{* *}$ & $8.12 \pm 1.36$ & $79.01 \pm 7.56$ & $25.38 \pm 2.97$ \\
23 & $66(55)$ & $\mathrm{YI}$ & 3.9 & $7.73 \pm 1.94$ & $80.64 \pm 8.03$ & $25.04 \pm 2.87$ \\
28 & $50(50)$ & $\mathrm{YI}$ & $16.7^{* * *}$ & $49.65 \pm 35.6$ & $9.96 \pm 9.51$ & $24.76 \pm 16.8$ \\
\hline
\end{tabular}

BTA: chromosome, LRT: Loglikelihood Ratio Test statistic with related significance, QTL: QTL variance component with related standard errors as provided by DMU, PG: additive polygenic variance component with related standard errors, Rest: residual variance component with related standard errors, aexpected position based on previous linkage analysis in brackets, ${ }^{*} P<0.10,{ }^{*} P<0.05$, ${ }^{* *} P<0.01$ chromosomewise

\section{Discussion}

A random-QTL model was applied to incorporate marker information into parameter estimation for each single QTL. The procedure allowed us to detect new QTL and to estimate the proportion of total genetic variance attributed to different QTL on six different Bos taurus autosomes for the udder health index and yield index traits in the Danish Holstein population. Variance estimates vary between 2 to $58 \%$ of the total variance for different QTL and seem to explain a major part of the variance at certain positions of the cattle genome.

\section{QTL for production traits}

QTL affecting production index traits have been detected in our study on chromosomes BTA 3, 5, 16, 23 and 28. Several of these QTL have been detected in prior scans for different populations (Spelman et al. 1996, Kühn et al. 1999, Ashwell et al. 2001, De Koning et al. 2001, Thomsen et al. 2001, Nadesalingam et al. 2001, Bennewitz et al. 2004).

To our knowledge the QTL for PI on BTA3 has not been identified in this chromosomal region. Only Ashwell et al. (2001) have reported a QTL on BTA3 for PI near by position 54 cM, which in fact has been in agreement with the result of our prior regression analysis (as shown in brackets of Table 1 in column 2). The shift of the position might be specific to the model applied. The compounded YI did not reach chromosomewise significance, but its peak has been identified near position $87 \mathrm{cM}$, which is very close to a QTL described by Skelding et al. (2010) showing associations between the bovine interleukin-12 and interleukin-23 receptor genes and protein yield. 
The QTL for MI and PI on BTA5 have been detected by Bonakdar et al. (2010) in a similar region between marker BMC1006 and ETH10. Although both index traits show high significance, the compounded YI did again not reach the significance level. Nonetheless, the peak was almost at the same position ( $38 \mathrm{cM})$. A possible explanation for this QTL might be the IGF-I gene polymorphism that has been associated with milk fat and protein in Holstein dairy cows (Bonakdar et al. 2010).

A new QTL for MI has been detected on BTA16. The closest QTL to our knowledge that has been detected for MI, is still approx. $40 \mathrm{cM}$ apart (Daetwyler et al. 2008). The QTL for PI in the same location has been detected earlier though by Lillehammer et al. in 2007. The compounded YI showed in contrast to BTA5 high significance at the same position of the chromosome. This was rather surprising because this chromosomal region has been chosen for investigation due to a strong QTL for conformation traits (Buitenhuis et al. 2007).

The QTL for Fl, MI and PI on BTA23 have been also detected by Bennewitz et al. (2004) in the same chromosomal region. But again the compounded YI did not show up as a significant QTL in our study, although the peak for YI was highest in the same region as it was for the individual indexes. This might be explained by the different weight of the individual indexes in the compounded index.

The final chromosome under investigation (BTA28) for production traits also revealed a QTL for PI at position $49 \mathrm{cM}$ and for $\mathrm{YI}$ at $50 \mathrm{cM}$. Even though QTL for MI and FI did not show significance in our QTL search, the highest peaks were also at the same position. These results are in good agreement with QTL detected in the identical region by Bagnato et al. (2008). Along with this chromosomal region a strong QTL for conformation traits has also been described by Buitenhuis et al. (2007) that might be in LD with the QTL alleles selected for production index traits.

One might argue that QTL in this study have only been detected with a single-trait-singleQTL model. As shown by Sørensen et al. (2003), the model will provide sufficient position estimates for QTL with small and big effects. The model dimension is very variable, and it usually has a good mixing character between the polygenic and QTL components and, thus, is easy to converge. There is no doubt, that the recent development using a genomewide panel of dense markers (SNPs) has the great advantage of targeting potentially all QTL simultaneously, whereas the traditional approach is limited due to their very stringent tests for statistical significance to identify QTL, so that only a limited fraction of the genetic variation will be explained by the identified QTL (Goddard \& Hayes 2009).

\section{QTL for the udder health index}

The QTL for udder health index on BTA7 has been confirmed by Ron et al. (2004). They reported a putative QTL for somatic cell score at a nearby position $(31.73 \mathrm{cM})$ on the chromosome. Our QTL for the udder health index on BTA23 has also been detected in the same marker bracket by Lund et al. (2008), although somatic cell score has been used as phenotypic trait in their study. Even though Lund et al. (2008) showed evidence for QTL affecting clinical mastitis, somatic cell score and udder conformation traits in the Danish Holstein Cattle on BTA5, the QTL for the udder health index on BTA5 did not reach significance in our study. The QTL for udder health index on BTA28, which has been 
identified in the same chromosomal region (Tal-Stein et al. 2010), dropped also below an appropriate level of significance in our QTL search.

\section{Variance components}

Overall, the QTL under investigation explained a proportion of 2 to $58 \%$ of the genetic variance. The genetic variance due to the QTL is assumed to be a precise partitioning of polygenic variance components. This is primarily, because the relationship among grandsires and sons of different grandsire families has been accounted for by the inclusion of many former generations to the pedigree material compared to Neuner et al. (2008), who included only the last three generations. In a granddaughter design (Weller et al. 1990) the grandsires are assumed to be unrelated, but the current approach took all known male and female ancestors of the grandsires and sons into account. As a result the residual variances are lower compared to the study of Szyda et al. (2005), even though the material used in their study was rather large with respect to the number of individuals genotyped for the QTL regions of interest and the number of daughters per bull. The same effect has been shown by Kučerová et al. (2006), where variances were higher when using a more restricted pedigree compared to an extended pedigree.

Another explanation for the rather small proportion of residual variance might be the use of DRPFs as the dependent variable, which has been shown to be advantageous for MAS. Estimated breeding values might be slightly less correct and potentially biased, so that the estimated variances might be affected. Efficient weighting of the dependent variable as applied in this study should also improve the results of parameter estimation (Thomsen 2006, Neuner et al. 2008).

An important influence for the precision of the estimation of variance components is also due to marker informativity. As pointed out by Druet et al. (2006), non-informative sires will have the probability of identity-by-descent with his son equal to 0.5 , which is identical to the additive relationship matrix, and therefore no information is available for the separation of QTL effects and the polygenic term. In order to counteract this fact, the setup of the study material has accounted for the non-informativity of sire families by choosing the most informative markers in the QTL regions (Thomasen et al. 2008).

Another way to account for this problem is to include genotypes of the female side, as it was originally planned in the development of routine genotyping for the MAS scheme, whereas data available for the current analysis consisted of genotypes of bulls only. Based on the large number of genotyped bulls, genotypes of some dams and maternal grandsires might have been reconstructed to improve information on QTL transmissions.

As an alternative Bolard \& Boichard (2002) showed how the information on maternal grandsire genotypes and, consequently, on QTL transmissions can be incorporated in the QTL mapping and subsequently used for the estimation of parameters.

One general problem still seems to remain unsolved: the overestimation of QTL variances. For several QTL the variance seemed to be overestimated with values up to $58 \%$ such as for i.e. YI and PI. This might be explained with the pre-selection of our data set as in many QTL studies before. Sires were always supposed to be QTL heterozygous and their sons should have high positive and high negative values for the phenotypic trait values (van der Werf et al. 2007). 
In conclusion, the study has identified some new QTL and provided some good estimates of the genetic variances due to the QTL. Despite the examples of applied MAS as described above, the application of MAS will be limited, because estimating effects and making predictions from modern genome-wide association studies has moved forward with an enormous progress. Even though newly detected QTL seem to be interesting from the scientific standpoint, many QTL are not applicable to commercial populations, or they need to be fine-mapped and confirmed with adequate methods first. Only a few QTL with sufficiently large effect to be economically viable for the large costs and logistical demands of implementation might then be used in MAS in some smallholder production systems (Marshall et al. 2011).

\section{References}

Ashwell MS, Van Tassell CP, Sonstegard TS (2001) A genome scan to identify quantitative trait loci affecting economically important traits in a US Holstein population. J Dairy Sci 84, 2535-2542

Bagnato A, Schiavini F, Rossoni A, Maltecca C, Dolezal M, Medugorac I, Sölkner J, Russo V, Fontanesi L, Friedmann A (2008) Quantitative trait loci affecting milk yield and protein percentage in a three-country Brown Swiss population. J Dairy Sci 91, 767-783

Bennewitz J, Reinsch N, Reinhardt F, Liu Z, Kalm E (2004) Top down preselection using marker assisted estimates of breeding values in dairy cattle. J Anim Breed Genet 121, 307-318

Bennewitz J, Reinsch N, Guiard V, Fritz S, Thomsen H, Looft C, Kühn C, Schwerin M, Weimann C, Erhardt G, Reinhardt F, Reents R, Boichard D, Kalm E (2004) Multiple quantitative trait loci mapping with cofactors and application of alternative variants of the false discovery rate in an enlarged granddaughter design. Genet 168, 1019-1027

Boichard D, Fritz S, Rossignol MN, Boscher MY, Malafosse A, Colleau JJ (2002) Implementation of markerassisted selection in French dairy cattle. Proceedings of the 7th WCGALP 33, 19-22

Bolard M, Boichard D (2002) Use of maternal information for QTL detection in a (grand)daughter design. Genet Sel Evol 34, 335-352

Bonakdar E, Rahmani HR, Edriss MA, Sayed Tabatabaei BE (2010) IGF-I gene polymorphism, but not its blood concentration, is associated with milk fat and protein in Holstein dairy cows. Genet Mol Res 9, 1726-1734

Buitenhuis AJ, Lund MS, Thomasen JR, Thomsen B, Nielsen VH, Bendixen C, Guldbrandtsen B (2007) Detection of quantitative trait loci affecting lameness and leg conformation traits in Danish Holstein cattle. J Dairy Sci 90, 472-481

Daetwyler HD, Schenkel FS, Sargolzaei M, Robinson JA (2008) A genome scan to detect quantitative trait loci for economically important traits in Holstein cattle using two methods and a dense single nucleotide polymorphism map. J Dairy Sci 91, 3225-3236

Danish Cattle Federation (2006) Principles of Danish cattle breeding. 8th ed. http://www.landbrugsinfo.dk/ Kvaeg/Avl/Sider/principles.pdf [last accessed 29.08.2011]

de Koning DJ, Schulman NF, Elo K, Moisio S, Kinos R, Vilkki J, Maki-Tanila A (2001) Mapping of multiple quantitative trait loci by simple regression in half-sib designs. J Anim Sci 79, 616-622

Druet T, Fritz S, Boichard D, Colleau JJ (2006) Estimation of Genetic Parameters for Quantitative Trait Loci for Dairy Traits in the French Holstein Population. J Dairy Sci 89, 4070-4076

Fernando RL, Grossman M (1989) Marker-assisted selection using best linear unbiased prediction. Genet Sel Evol 21, 467-477

Georges M, Nielsen D, Mackinnon M, Mishra A, Okimoto R, Pasquino AT, Sargeant LS, Sorensen A, Steele MR, Zhao X, Womac JE, Hoeschele I (1995). Mapping quantitative trait loci controlling milk production in dairy cattle by exploiting progeny testing. Genet 139, 907-920 
Goddard ME, Hayes BJ (2002) Optimisation of response using molecular data. Proc 7th World on Genetics Applied to Livestock Production, Montpellier, France, August 2002, Session 22, 23

Goddard ME, Hayes BJ (2007) Genomic selection. J Anim Breed Genet 124, 323-330

Goddard ME, Hayes BJ (2009) Mapping genes for complex traits in domestic animals and their use in breeding programs. Nat Rev Genet 10, 381-391

Hiendleder S, Thomsen H, Reinsch N, Bennewitz J, Leyhe-Horn B, Looft C, Xu N, Medjugorac I, Russ I, Kühn C, Brockmann GA, Blümel J, Brenig B, Reinhardt F, Reents R, Averdunk G, Schwerin M, Förster M, Kalm E, Erhardt G (2003) Mapping of QTL for body conformation and behavior in cattle. J Hered 94, 496-506

Jensen J, Mäntysaari E, Madsen P, Thompson R (1997) Residual maximum likelihood estimation of (co)variance components in multivariate mixed linear models using average information. J Indian Soc Agric Stat 49, 215-236

Klungland H, Sabry A, Heringstad B, Olsen HG, Gomez-Raya L, Våge DI, Olsaker I, Ødegård J, Klemetsdal G, Schulman N, Vilkki J, Ruane J, Aasland M, Rønningen K, Lien S (2001) Quantitative trait loci affecting clinical mastitis and somatic cell count in dairy cattle. Mamm Genome 12, 837-842

Kučerová J, Lund MS, Sørensen P, Sahana G, Guldbrandtsen B, Nielsen VH, Thomsen B, Bendixen C (2006) Multi-trait quantitative trait loci mapping for milk production traits in Danish Holstein cattle. J Dairy Sci 89, 2245-2256

Kühn C, Freyer G, Weikard R, Goldammer T, Schwerin M (1999) Detection of QTL for milk production traits in cattle by application of a specifically developed markermap of BTA6. Anim Genet 30, 333-340

Lande R, Thompson R (1990) Efficiency of marker-assisted selection in the improvement of quantitative traits. Genet 124, 743-56

Lien S, Gomez-Raya L, Steine T, Fimland E, Rogne S (1995) Associations between Casein Haplotypes and Milk Yield Traits. J Dairy Sci 78, 2047-2056

Lillehammer M, Árnyasi M, Lien S, Olsen HG, Sehested E, Ødegård J, Meuwissen THE (2007) A Genome Scan for Quantitative Trait Locus by Environment Interactions for Production Traits. J Dairy Sci 90, 3482-3489

Liu Z, Reinhardt F, Bünger A, Reents R (2004) Derivation and Calculation of Approximate Reliabilities and Daughter Yield-Deviations of a Random Regression Test-Day Model for Genetic Evaluation of Dairy Cattle. J Dairy Sci 87, 1896-1907

Lund MS, Guldbrandtsen B, Buitenhuis AJ, Thomsen B, Bendixen C (2008) Detection of Quantitative Trait Loci in Danish Holstein Cattle Affecting Clinical Mastitis, Somatic Cell Score, Udder Conformation Traits, and Assessment of Associated Effects on Milk Yield. J Dairy Sci 91, 4028-4036

Marshall K, Quiros-Campos C, van der Werf JHJ, Kinghorn B (2011) Marker-based selection within smallholder production systems in developing countries. Livestock Science 136, 45-54

Meuwissen THE, Goddard ME (1996) The use of marker haplotypes in animal breeding schemes. Genet Sel Evol 28, 161-176

Nadesalingam J, Plante Y, Gibson JP (2001) Detection of QTL for milk production on chromosomes 1 and 6 of Holstein cattle. Mamm Genome 12, 27-31

Neuner S, Emmerling R, Thaller G, Götz KU (2008) Strategies for Estimating Genetic Parameters in MarkerAssisted Best Linear Unbiased Predictor Models in Dairy Cattle. J Dairy Sci 91, 4344-4354

Neuner S, Edel C, Emmerling R, Thaller G, Götz KU (2009) Precision of genetic parameters and breeding values estimated in marker assisted BLUP evaluation. Genet Sel Evol 41, 26-36

Piepho HP (2001) A quick method for computing approximate threshold for quantitative trait loci detection. Genetics 157, 425-432

Ron M, Feldmesser E, Golik M, Tager-Cohen I, Kliger D, Reiss V, Domochovsky R, Alus O, Seroussi E, Ezra E, Weller Jl (2004) A complete genome scan of the Israeli Holstein population for quantitative trait loci by a daughter design. J Dairy Sci 87, 476-90

Schrooten C, Bovenhuis H, Coppieters W, van Arendonk JAM (2000) Whole genome scan to detect quantitative trait loci for conformation and functional traits in dairy cattle. J Dairy Sci 83, 795-806 
Skelding A, Schenkel FS, Sharma BS, Verschoor C, Pant S, Biggar G, Boermans H, Karrow N (2010) Identification of single nucleotide polymorphisms in the bovine interleukin-12 and interleukin-23 receptor genes and their associations with health and production traits in Holstein cows, J Dairy Sci 93, 4860-4871

Spelman RJ, Coppieters W, Karim L, van Arendonk JA, Bovenhuis H (1996) Quantitative trait loci analysis for five milk production traits on chromosome six in the Dutch Holstein-Friesian population. Genetics 144, 1799-1808

Spelman RJ, Huisman AE, Singireddy SR, Coppieters W, Arranz J, Georges M, Garrik DJ (1999) Quantitative trait loci analysis on 17 non-production traits in the New Zealand dairy population. J Dairy Sci 82, 2514-2516

Spelman RJ, Keehan M, Obolonkin V, Coppieters W (2007) Application of genomic information in a dairy cattle breeding scheme. Proc Assoc Adv Anim Breed Genet 17, 471-478

Sørensen P, Lund MS, Guldbrandtsen B, Jensen J, Sorensen DA (2003) A comparison of bivariate and univariate QTL mapping in livestock populations. Genet Sel Evol 35, 605-622

Szyda J, Liu Z, Reinhardt F, Reents R (2005) Estimation of Quantitative Trait Loci Parameters for Milk Production Traits in German Holstein Dairy Cattle Population. J Dairy Sci 88, 356-367

Tal-Stein R, Fontanesi L, Dolezal M, Scotti E, Bagnato A, Russo V, Canavesi F, Friedmann A, Soller M, Lipkin E (2010) A genome scan for quantitative trait loci affecting milk somatic cell score in Israeli and Italian Holstein cows by means of selective DNA pooling with single- and multiple-marker mapping. J Dairy Sci 93, 4913-4927

Thomasen JR, Guldbrandtsen B, Sørensen P, Thomsen B, Lund MS (2008) Quantitative Trait Loci Affecting Calving Traits in Danish Holstein Cattle. J Dairy Sci 91, 2098-2105

Thomsen H, Reinsch N, Xu N, Looft C, Gruppe S, Kühn C, Brockmann GA, Schwerin M, Leyhe-Horn B, Hiendleder S, Erhardt G, Medjugorac I, Russ I , Förster M, Brenig B, Reinhardt F, Reents R, Blümel J, Averdunk G, Kalm $E$ (2001) Comparison of estimated breeding values, daughter yield deviations and de-regressed proofs within a whole genome scan for QTL. J Anim Breed Genet 118, 357-370

Thomsen $\mathrm{H}$ (2006) The choice of phenotypes for use of marker assisted selection in dairy cattle. Proc 7th World on Genetics Applied to Livestock Production, Montpellier, France, August 2002, Session 22, 26

van der Werf JHJ, Marshall K, Lee S (2007) Methods and experimental designs for detection of QTL in sheep and goats. Small Rumin Res 70, 21-31

Wang T, Fernando RL, van der Beek S, Grossman M, van Arendonk JAM (1995) Covariance between relatives for marked quantitative trait locus. Genet Sel Evol 27, 251-274

Weller JI, Kashi Y, Soller M (1990) Power of daughter and granddaughter designs for determining linkage between marker loci and quantitative trait loci in dairy cattle. J Dairy Sci 73, 2525-2537

Zhang Q, Boichard D, Hoeschele I, Ernst C, Eggen A, Murkve B, Pfister-Genskow M, Witte LA, Grignola FE, Uimari P, Thaller G, Bishop MD (1998) Mapping quantitative trait loci for milk production and health of dairy cattle in a large outbred pedigree. Genet 149, 1959-1973

Received 7 January 2011, accepted 28 June 2011.

Corresponding author:

Hauke Thomsen

email: haukethomsen@me.com

Department of Genetics and Biotechnology, Aarhus University - Research Centre Foulum, Blichers Allé, DK8830 Tjele, Denmark 